\title{
Azadirachtin on Oligonychus yothersi in yerba mate Ilex paraguariensis
}

\author{
Efeito da azadiractina sobre Oligonychus yothersi (McGregor) \\ (Acari: Tetranychidae) na cultura da erva-mate (Ilex paraguariensis St Hil.)
}

\author{
Luis Francisco Angeli Alves ${ }^{I^{*}}$ Claudecir Castilho Martins ${ }^{I}$ \\ Ana Paula Mamprim ${ }^{\mathrm{I}}$ Marcos Botton ${ }^{\mathrm{II}}$
}

\section{ABSTRACT}

The red mite Oligonychus yothersi is one of the main pests of yerba mate in Brazil The damage this mite causes leads to leaf drop and decreased production. There are no registered acaricides for use in yerba mate; thus, laboratory and field experiments were performed to evaluate the effect of azadirachtin $\left(\right.$ Azamax $\left.^{\circledR}, 250 \mathrm{~mL} 100 \mathrm{~L}^{-1}\right)$ for the control of the red mite in yerba mate. In the laboratory, azadirachtin was applied to yerba mate leaf disks before (residual contact) and after (direct contact) infestation with 15 newly emerged red mite adult females. The effect of azadirachtin on mite behavior was evaluated in arenas with treated and untreated yerba mate leaves, and the number of mites in both areas was recorded. Ovicidal action was evaluated by applying azadirachtin to eggs and recording egg hatching. In the field, two applications of the product were performed $(1 \mathrm{~L}$ spray liquid plant ${ }^{-1}$ ) with a 7-day interval. The numbers of living mites were evaluated at 7,14 and 21 days following the first application on randomly collected leaves. It was observed 86.6 and $91.4 \%$ of mortality following $24 \mathrm{~h}$ of residual and direct contact, respectively. Repellent (62\% of individuals leaving the treated area) and ovicidal (98.9\% decrease in egg hatching) effects were also observed. The mite population in the yerba mate crop field had decreased by 59.6\% at 14 days after the first application of azadirachtin. The results show the potential of azadirachtin for the control of $\boldsymbol{O}$. yothersi in yerba mate in Brazil.

Key words: neem, alternative control, yerba mate pest.

\section{RESUMO}

O ácaro Oligonychus yothersi é uma das principais pragas da cultura da erva-mate. Seus danos levam à queda das folhas e redução da produção. Não há acaricidas registrados para uso na erva-mate e por isso foram realizados experimentos em laboratório e a campo para avaliar o efeito da azadiractina (Azamax $\left.{ }^{\circledR}, 250 m L 100 L^{-1}\right)$, visando ao controle da espécie na cultura da erva mate. Em laboratório, o produto foi aplicado em discos de folha de erva-mate antes (contato residual) e depois (contato direto) da infestação com 15 fêmeas adultas recém-emergidas do ácaro vermelho. $A$ ação do produto no comportamento do ácaro foi avaliada em arenas com folhas de erva-mate tratadas e não tratadas, registrando-se o número de ácaros em ambas as áreas. Além disso, a ação ovicida foi avaliada, aplicando-se o produto sobre ovos e registrando a sua eclosão. No campo, foram realizadas duas aplicações do produto (1L de calda planta $\left.^{-1}\right)$, espaçadas sete dias. Avaliou-se o número de ácaros vivos, aos 7, 14 e 21 dias após a primeira aplicação, em folhas coletadas aleatoriamente. Observou-se ação acaricida (86,6 e $91,4 \%$ de mortalidade após $24 \mathrm{~h}$, respectivamente, por contato residual e direto; repelência (62\% dos individuos abandonando a área tratada) e ação ovicida (redução de 98,9\% na eclosão). $\mathrm{Na}$ lavoura de erva-mate, a redução populacional do ácaro foi de $59.6 \%$ aos 14 dias após a primeira aplicação do produto. Os resultados demonstram o potencial de emprego da azadiractina para o controle de $\boldsymbol{O}$. yothersi na cultura da erva-mate.

Palavra-chave: nim, controle alternativo, praga da erva-mate.

\section{INTRODUCTION}

Oligonychus yothersi (avocado red mite) is a polyphagous mite occurring in avocado, coffee, eucalyptus, mango, ornamental plants and yerba mate (MORAES \& FLECHTMANN, 2008). In yerba mate, this species occurs under conditions of high-density cultivation. Its colonies are found on the adaxial side of older leaves (mature) (SILVA et al., 2001), causing crinkling and dark spots due to leaf necrosis and leading to early leaf drop

\footnotetext{
'Laboratório de Biotecnologia Agrícola, Universidade Estadual do Oeste do Paraná (UNIOESTE), 85819-110, Cascavel, PR, Brasil. E-mail: luis.alves@unioeste.br. *Corresponding author.

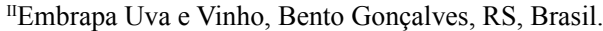


(ALVES et al., 2004). In Brazil, no miticides are registered for the control of this mite in yerba mate (AGROFIT, 2015), which encourages the use of chemical insecticides by growers. However, there is restriction concerning the presence of toxic residues in leaves used in infusions. Alternatives are therefore needed, such as insecticidal plants (PASINI et al., 2003) and biological control with entomopathogenic fungi (OLIVEIRA et al., 2004).

Neem (Azadiracta indica) is a plant of Asian origin with well-known insecticidal action causing feeding inhibition, repellency, interference with pest growth and a decrease in fertility and fecundity (MORDUE (LUNTZ) \& NISBET, 2000). Neem insecticides are safer than chemical for human health and the environment being less toxic to predatory mites in different crops (SCHLESENER et al., 2013; BERNARDI et al., 2013). However, the composition of neem-based commercial products in Brazil varies according to the origin of plants used in the formulation. For this reason, a standardized product with a high degree of purity is desirable (BRITO et al., 2006; BERNARDI et al., 2013).

Azadirachtin $\left(\right.$ Azamax $\left.^{\circledR} 12 \mathrm{~g} \mathrm{~L}^{-1}\right)$ was the first insecticide registered for pest control in Brazil being also authorized for use in organic agriculture (IBD, 2015; AGROFIT, 2015). However, there is no information on its effects to control $\boldsymbol{O}$. yothersi in yerba mate. In this study, the effect of azadirachtin on o. yothersi was evaluated in the laboratory and in a commercial cultivation of yerba mate.

\section{MATERIALS AND METHODS}

Oligonychus yothersi rearing: laboratory population of $\boldsymbol{O}$. yothersi was established in yerba mate seedlings grown in pots containing soil + humus and maintained in a climate-controlled greenhouse $\left(27 \pm 1^{\circ} \mathrm{C}, 60-70 \%\right.$ relative humidity).

The commercial product Azamax $^{\circledR}$ (azadirachtin A/B $12 \mathrm{~g} \mathrm{~L}^{-1}$, inert ingredients $988 \mathrm{~g}$ $\mathrm{L}^{-1}$; UPL Brazil) was used in all experiments at a concentration of $250 \mathrm{~mL}$ of commercial product per 100L of water.

Mortality of red mite adults: yerba mate leaves were immersed in $1 \%$ sodium hypochlorite for 1 minute and then washed with distilled water. Leaf disks of $226 \mathrm{~mm}^{2}$ were obtained using a metal hole puncher. For the evaluation of the effects of direct contact, 15 newly emerged and unsexed adult mites were placed on the adaxial side of disks, using a thin soft brush made of hair (size 00). Disks were placed in Petri dishes and sprayed with $1 \mathrm{~mL}$ of $0.25 \%$ commercial product, using a Potter spray tower $(0.7$

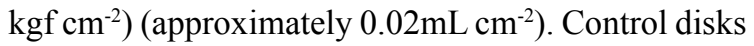
were sprayed with distilled water. Following spraying, the disks were transferred into Petri dishes containing a layer of polyacrylamide gel and placed in a growth chamber $\left(25 \pm 1^{\circ} \mathrm{C}, 60 \pm 10 \%\right.$ relative humidity and $12 \mathrm{~h}$ light: $12 \mathrm{~h}$ dark photoperiod). Twelve leaf disks were used (replicates) for azadirachtin and control treatment. For evaluation of the effects of residual contact, the same procedure was adopted, but the mites were placed on the leaf disks after the liquid had been sprayed and allowed to dry.

Mortality was evaluated $24 \mathrm{~h}$ after the azadirachtin application using a stereomicroscope. Mites that did not respond to the touch of the brush were considered dead.

Effect on eggs: a total of 24 yerba mate leaf disks were used. Twenty adult females of $\boldsymbol{O}$. yothersi were placed on each leaf disk for $24 \mathrm{~h}$ to allow egg laying. Mites were then removed, and 15 eggs were left on each disk, with the excess of eggs being removed by punching. Twelve disks were then sprayed with commercial product $0.25 \%$, and the remaining were sprayed with distilled water (control). Following drying (approximately 30 minutes), the disks were transferred into Petri dishes containing polyacrylamide gel and incubated. The number of hatched larvae was evaluated daily for 7 days using a stereomicroscope.

Repellent effect: following cleaning and disinfection, yerba mate leaves were cut into rectangles $(2 \times 4 \mathrm{~cm}$, width $\times$ length $)$ forming an arena divided longitudinally by the central nerve. Onehalf of the leaf was immersed in azadirachtin for 15 seconds, and the other was left untreated. The leaves were placed horizontally and dried in the shade. Ten unsexed adult mites were then placed on the central nerve of the adaxial side of each leaf. Twelve replicates (leaves) were used. Evaluations were performed at 5 min and at 1, 6, 12 and $24 \mathrm{~h}$ following mite release, using a stereomicroscope. Numbers of mites present in the treated and untreated areas were recorded.

Evaluation in yerba mate field cultivation: the experiment was conducted in a commercial cultivation of yerba mate on an organic farm located in Chopinzinho, state of Paraná (2551'54.63”S, $\left.52^{\circ} 35^{\prime} 05.38^{\prime \prime} \mathrm{W}, 809 \mathrm{~m}\right)$. Twenty trees of similar size and height ( 1.5 to $2 \mathrm{~m}$ ) and 15 years of age were randomly selected, with $2 \mathrm{~m}$ distance between the plants and $3 \mathrm{~m}$ between the rows. Ten plants were used for the azadirachtin and control treatments.

Population sampling was performed in the selected plants on August 28, 2013 before 
application of the azadirachtin, with collection of 20 mature leaves infested with $\boldsymbol{O}$. yothersi (ALVES et al., 2004). Mite presence in the leaves was evaluated at the laboratory with a stereomicroscope. The first application of azadirachtin was performed using $1 \mathrm{~L}$ of spray liquid/plant using a sprayer with a D6 nozzle and coupled to a tractor $\left(21 \mathrm{kgf} \mathrm{cm}^{-2}\right)$. A second azadirachtin application was performed after 7 days. The leaf mite populations were evaluated at 9, 14 and 21 days following the first application.

Daily temperatures (minimum, medium and maximum) and rainfall for the experimental period were obtained from the Simepar $<$ www.simepar.br $>$.

Statistical analysis: a completely randomized experimental design was used. The laboratory experiments were repeated three times for confirmation of the results. For the field experiment, a split-plot in time experimental design was used, with the split-plots corresponding to the different times following treatment application.

The mortality from direct or residual action data was compared with Student's t-test $(P>0.05)$, using Microsoft Excel ${ }^{\circledR}$ software. Data obtained from all experiments were tested for normality (ShapiroWilk), found to meet the assumptions and subjected to an analysis of variance, followed by Tukey's test $(P<0.05)$, using Sisvar software (FERREIRA, 2011).

The Repellency Index (RI) proposed by Lin et al. (1990) was estimated to compare the response among treatments and calculated with the equation RI $=2 \mathrm{G} /(\mathrm{G}+\mathrm{P})$ where $\mathrm{G}=$ is the $\%$ mites in the treated area and $\mathrm{P}$ is the $\%$ mites in the control area. Values were classified as $\mathrm{RI}=1$ neutral plant, $\mathrm{RI}<1$ repellent plant, and RI $>1$ attractive plant. As a safety margin for that classification, the value of the standard error for each treatment was added/subtracted.

The efficiency of azadirachtin in the laboratory was calculated using the SchneiderOrelli formula and in the field using the Henderson-
Tilton formula <http://www.ehabsoft.com/ldpline/ onlinecontrol.htm $>$.

\section{RESULTS AND DISCUSSION}

Mortality of red mite adults: Azadirachtin presented direct and residual miticide action. In the direct-effect assay, mites presented decreased movement immediately following azadirachtin application, and the mite population decreased by $91.6 \%$ after $24 \mathrm{~h}$. In the residual-effect assay, mites started moving more intensely following placement in leaves treated with azadirachtin resulting in $88.4 \%$ mortality after $24 \mathrm{~h}$. These values were lower than those observed for the direct effect ( $91.6 \%$ mortality) (Table 1). The mortality observed for the control treatment may have been due to mite handling because no significant differences between the two assays were observed, varying between 7.7 and 8.3\%.

Effects of azadirachtin on $\boldsymbol{O}$. yothersi have been previously observed. Application of a commercial neem oil formulation (1500 ppm azadirachtin) at $1 \%$ to second instar nymphs was observed to cause $77 \%$ nymph mortality and decreased fecundity in the surviving adults (PASINI et al., 2003). In the present study; however, a higher mortality percentage was obtained using a commercial product in a concentration $75 \%$ lower. This can be attributed to the standardized formulation of the commercial product (BRITO et al., 2006; BERNARDI et al., 2012).

Similar effects of azadirachtin have been reported for the two-spotted spider mite Tetranychus urticae (Koch) (Acari: Tetranychidae), but in that study, azadirachtin was used at higher concentrations ( 0.3 to $3.6 \%$ ) (BERNARDI et al., 2012; SCHLESENER et al., 2013).

Effects on eggs: the percentage of nymphs produced was $1.1 \%$ with azadirachtin treatment

Table 1 - Mortality of adult red mites, Oligonychus yothersi, in yerba mate $24 \mathrm{~h}$ after the application of azadirachtin $(0.25 \%)$ in the laboratory $\left(25 \pm 1^{\circ} \mathrm{C}\right.$ and $12 \mathrm{~h}$ light $/ 12 \mathrm{~h}$ dark photoperiod $)$.

\begin{tabular}{|c|c|c|c|c|c|}
\hline Treatment & Direct contact & Efficiency $^{1}(\%)$ & Residual contact & Efficiency $^{1}(\%)$ & Egg hatching (\%) \\
\hline $\operatorname{Azamax}^{\circledR}$ & $91.6 \pm 3.64 \mathrm{a}^{*}$ & 90.8 & $88.4 \pm 11.63 \mathrm{a}$ & 87.4 & $1.1 \pm 3.75 b$ \\
\hline Control & $8.3 \pm 4.94 b$ & - & $7.7 \pm 6.24 b$ & - & $93.8 \pm 4.39^{\mathrm{a}}$ \\
\hline CV (\%) & 26.67 & & 13.51 & & 8.77 \\
\hline
\end{tabular}

Averages $( \pm \mathrm{SE})$ followed by the same letter within the same column are not significantly different according to the Tukey test $(P<0.05)$; $\mathrm{CV}=$ coefficient of variation

${ }^{1}$ Efficiency calculated using the Schneider-Orelli formula.

*statistically significant difference between direct and residual effects according to Student's t-test $(P<0.05)$. 
and $93.8 \%$ for the control treatment (Table 1). Azadirachtin can cause partial or complete egg sterility (SCHMUTTERER, 1990), and no hatching of T. urticae eggs treated with Neemseto ${ }^{\circledR}$ has been observed, independently of the concentration tested $(0.25,0.5$ and $1 \%)$ (BRITO et al., 2006). In addition, azadirachtin sprayed on $\boldsymbol{T}$. urticae eggs decreased hatching by 50 to $70 \%$ (SCHLESENER et al., 2013). This is the first information related to azadirachtin on $\boldsymbol{O}$. yothersi eggs. It is likely that azadirachtin pass through the chorion membrane, affecting both cell division and protein synthesis, making embryos inviable (MORDUE (LANTZ) \& NISBET, 2000).

Repellent effect: according to the repellency index, azadirachtin went from neutral to repellent $1 \mathrm{~h}$ after the release of the mites and maintained its repellency during the experiment. However, the percentage of repelled mites was not significantly different from the control until $12 \mathrm{~h}$ after mite release. After $24 \mathrm{~h}$, the percentage of repelled mites was approximately twice the initial value (increasing from 48 to $90 \%$ ) and was significantly different from the control. Furthermore, many mites were observed in the water surrounding the disk (Table 2).

BRITO et al. (2006) also observed the repellent effects of azadirachtin (Neemseto ${ }^{\circledR}, 0.25$, 0.5 and $1 \%$ ) against T. urticae, with 96 to $98 \%$ repellency. However, these values were observed 3 days after mites were placed on the azadirachtintreated areas. Regarding the observed mite escape, neem-based products possess translaminar properties (SOUZA \& VENDRAMIN, 2005), and the product may have spread from the treated to the untreated half of the leaf a few hours after application, making the whole disk inadequate and forcing the mites to escape into the surrounding water. This was not observed by BRITO el al.
(2006), using semicircles leafs, immersed and not immersed in the treatment solution, with subsequent mite release.

Evaluation in yerba mate field cultivation: the average number of mites was not significantly different between the plants used for the Azamax ${ }^{\circledR}$ and for the control treatment (average 15.9 and 13.4 mites $/$ leaf $^{-1}$, respectively; table 3 ). However, it was observed a significantly decreased in the mite population 7 days after the first application (46.4\% efficiency). No significant changes were observed in the mite population in the untreated plants $(9.9$ mites leaf $\left.{ }^{-1}\right)$. Fourteen days after the first application, the efficiency of the treatment reached $59.6 \%$ and the population in the untreated plants practically doubled, with an average of 20 individuals per leaf (Table 3 ).

In the last evaluation, 21 days after the first application, the mite population in the Azamax ${ }^{\circledR}$ treated and control plants was lower than the initial populations, with no difference existing between treatments. During September 15 and 23 in 2013 (between the second and third population evaluation) it was observed a higher rainfall when compared with the previous weeks (Figure 1). It is possible that both the product and the mites were removed by the rain explaining the results observed. Negative effects of rain on mite populations have been previously observed for $\boldsymbol{O}$. ilicis on coffee plants (FRANCO et al., 2008; PEDRO NETO et al., 2010), and for $\boldsymbol{O}$. yothersi (ALVES et al., 2004).

When applied at a concentration of $1.2 \%$, azadirachtin has been observed to be effective for the control of $\boldsymbol{T}$. urticae in strawberry crops, with effectiveness levels similar to the ones observed in the present study (BERNARDI et al., 2012). However, the action of azadirachtin may be considered slow considering the growth potential of mite populations because the surviving mites

Table 2 - Repellent effect of azadirachtin $(0.25 \%)$ on Oligonychus yothersi on yerba mate leaves $\left(25 \pm 1^{\circ} \mathrm{C}\right.$ and $12 \mathrm{~h}$ light/12h dark photoperiod).

\begin{tabular}{lccc}
\hline Time following mite release $(\mathrm{h})$ & Repelled mites $(\%)$ & Repellency index & Classification \\
\hline 0.25 & $48 \pm 8.0 \mathrm{~b}$ & 1 & Neutral \\
1 & $62 \pm 8.0 \mathrm{~b}$ & 0.8 & Repellent \\
6 & $72 \pm 3.7 \mathrm{ab}$ & 0.9 & Repellent \\
12 & $72 \pm 8.6 \mathrm{ab}$ & 0.7 & Repellent \\
24 & $90 \pm 4.4 \mathrm{a}$ & 0.5 & Repellent \\
$\mathrm{CV}(\%)=24.48$ & & & \\
\hline
\end{tabular}

Averages $( \pm \mathrm{SE})$ followed by the same lower case letter within the same column are not significantly different according to Tukey's test $(P<0.05)$; $\mathrm{CV}=$ coefficient of variation. 
Table 3 - Average number of living red mites, Oligonychus yothersi, following the application of azadirachtin $0.25 \%$ to yerba mate leaves under field conditions (Chopinzinho, Paraná, August - September 2013).

\begin{tabular}{|c|c|c|c|c|c|c|c|}
\hline \multirow[t]{2}{*}{ Plants } & \multirow{2}{*}{$\begin{array}{c}\text { Pre-sampling } \\
\mathrm{n}\end{array}$} & \multicolumn{2}{|c|}{ 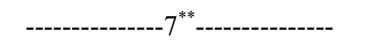 } & \multicolumn{2}{|c|}{-----------14---------------- } & \multirow{2}{*}{$\begin{array}{c}21 \\
\mathrm{n}\end{array}$} & \multirow[b]{2}{*}{$\% \mathrm{C}$} \\
\hline & & $\mathrm{n}$ & Efficiency (\%) & $\mathrm{n}$ & $\% \mathrm{C}$ & & \\
\hline Control & $13.4 \pm 1.33 \mathrm{abA}$ & $9.9 \pm 1.37 \mathrm{bcA}$ & - & $20.0 \pm 3.4 \mathrm{aA}$ & - & $2.6 \pm 0.4 \mathrm{cA}$ & - \\
\hline Treated & $15.9 \pm 2.94 \mathrm{aA}$ & $7.5 \pm 1.74 \mathrm{cA}$ & 33.5 & $9.6 \pm 1.9 \mathrm{abB}$ & 59.6 & $2.9 \pm 0.5 \mathrm{cA}$ & 21.6 \\
\hline \multicolumn{8}{|l|}{$\mathrm{CV} 1(\%)=31.5$} \\
\hline CV $2(\%)=21.39$ & & & & & & & \\
\hline
\end{tabular}

Averages $( \pm \mathrm{SE})$ followed by the same lower case letter within the same line and upper case within the same column are not significantly different according to the Tukey test, at $P<0.05$.

${ }^{*}$ First application of Azamax ${ }^{\circledR}$.

${ }^{* *}$ Second application of Azamax ${ }^{\circledR}$.

$\% \mathrm{C}=$ Efficiency calculated using the Henderson-Tilton formula.

C.V. 1 = coefficient of variation for comparison between different times; C.V. 2 = coefficient of variation for comparison between the Azamax and control treatments.

can produce progeny in 7 days (ALVES et al., 2004). Therefore, reapplication may be necessary to increase the azadirachtin effects on mites due to the addition of new individuals in the population (BERNARDI et al., 2012).

The observed decrease in $\boldsymbol{O}$. yothersi populations 7 days after azadirachtin application is in accordance with the occurrence of a translocation peak on the plant for up to 5 days and storage in leaves for up to 8 days (MARTINEZ, 2002). In addition, the action of neem products decreases with time, which is attributed to environmental factors mainly temperature, sunlight UV radiation and rain (CABONI et al., 2006; BERNARDI et al., 2012; SCHLESENER et al., 2012). The short residual action of the product should be compensated with reapplication at 7 days intervals (CABONI et al.,
2006; BERNARDI et al., 2012), which was also observed for the yerba mate crop.

In the case of yerba mate, the absence of toxic residues after application of $\mathrm{Azamax}^{\circledR}$ is an advantage because the leaves are used for beverages and extraction of caffeine and others derivatives. In addition, the use of azadirachtin has a reduced effect on predatory mites being an alternative for conservative biological control (BRITO et al., 2006; BERNARDI et al., 2012).

\section{CONCLUSION}

Azadirachtin $0.25 \%$ has effect on $\boldsymbol{O}$. yothersi eggs and adults, causing mortality and repellency being an alternative to control $\boldsymbol{O}$. yothersi in yerba mate crops.

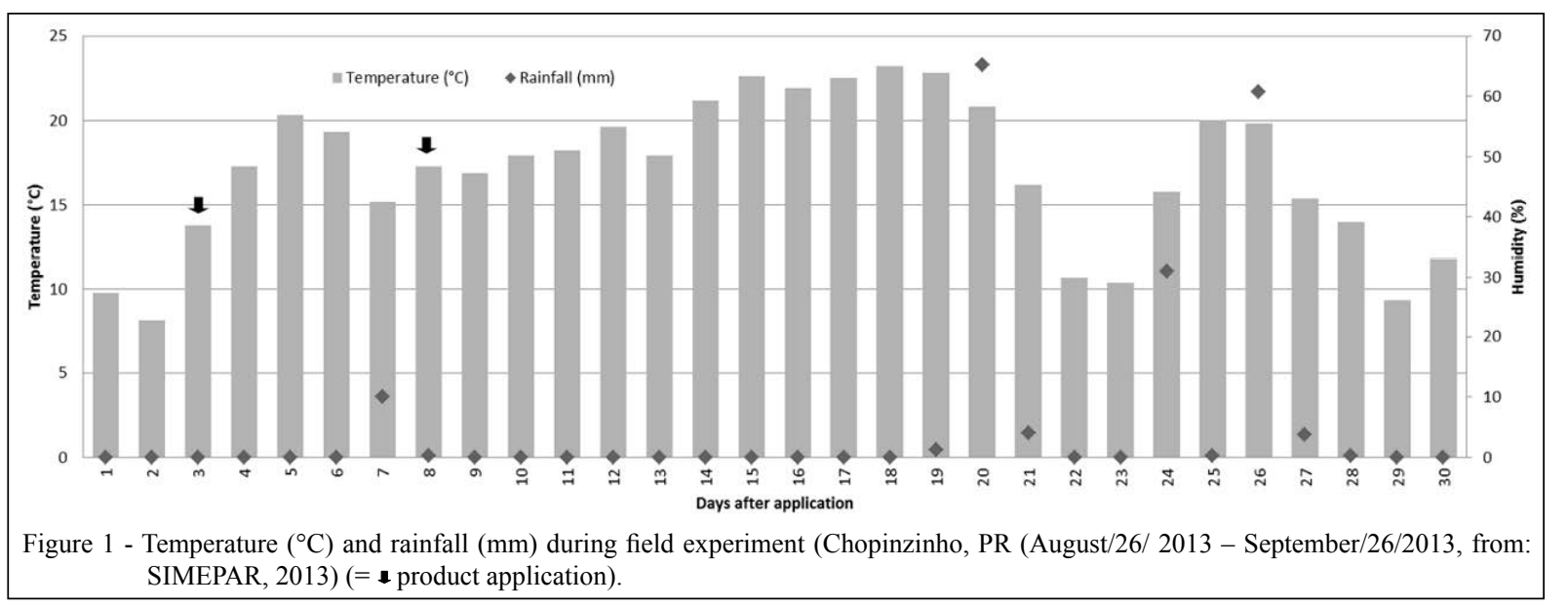

Ciência Rural, v.46, n.10, out, 2016. 


\section{ACKNOWLEDGMENTS}

The authors wish to thank the Conselho Nacional de Desenvolvimento Científico e Tecnológico $(\mathrm{CNPq})$ for the financial support to the Biological and Alternative Pest Control of Yerba Mate (Ilex paraguariensis) crop project Controles Biológico e Alternativo de pragas da cultura da erva mate (Ilex paraguariensis) - MCT/CNPq 14/2010 (process 473391/2010-4).

\section{REFERENCES}

AGROFIT. Sistemas de agrotóxicos fitossanitários. Ministério da Agricultura, Pecuária e Abastecimento. Coordenação Geral de Agrotóxicos e Afins/DFIA/DAS. 2012. Available from: $<$ http://extranet.agricultura.gov.br/agrofit_cons/principal_ agrofit cons>. Accessed: Feb. 27, 2015

ALVES, L.F.A. et al. Biology and damage of Oligonychus yothersi (McGregor) (Acari: Tetranychidae) on Ilex paraguariensis. Arquivos do Instituto Biológico, v.71, n.2, p.211-214, 2004 Available from: <http://www.biologico.sp.gov.br/docs/arq/V71_2/ alves.pdf $>$. Acessed: Feb. 27, 2015.

BERNARDI, D. et al. Effects of azadirachtin on Tetranychus urticae (Acari: Tetranychidae) and its compatibility with predatory mites (Acari: Phytoseiidae) on strawberry. Pest Management Science, v.69, n.1, p.75-80, 2012. Available from: <http://wileyonlinelibrary. com/10.1002/ps.3364>. Accessed: May 15, 2015.

BRITO, H.M. et al. Toxicity of neem (Azadirachta indica A. Juss.) formulations for twospotted spider mite and Euseius alatus De Leon and Phytoseiulus macropilis (Banks) (Acari: Phytoseiidae). Neotropical Entomology, v.35, n.4, p.500-505, 2006. Available from: $<$ http://dx.doi. org/10.1590/S1519-566X2006000400012>. Accessed: May 15, 2015.

CABONI, P. el al. Residues and persistence of neem formulations on strawberry after field treatment. Journal of Agricultural and Food Chemisty, v.54, p.10026-10032, 2006. Available from: <pubs.acs. org/doi/abs/10.1021/jf062461v>. Accessed: Mar. 4, 2015.

FRANCO, R.A. et al. Population dynamics of Oligonychus ilicis (McGregor, 1917) (Acari: Tetranychidae) in coffee plants and of their associated Phytoseiids. Coffee Science, v.3, n.1, p.38-46, 2008. Available from: <https://www.coffeescience.ufla.br/index. php/Coffeescience/article/view/71>. Accessed: March 15, 2015.

FERREIRA, D.F. Sisvar: a computer statistical analysis system. Ciência e Agrotecnologia, v.35, n.6, p.1039-1042, 2011. Available from: <http://dx.doi.org/10.1590/S1413-70542011000600001>. Accessed: Oct. 04, 2014.

IBD. IBD Certificações. Available from: <http:// ibd.com.br/pt/ClienteResultadoPesquisa Impressao. aspx ?INSUMO=1\&CLIENTE $=\mathrm{I} 0036 \% 20 \mathrm{SP}>$. Accessed: Aug. 19, 2015

MARTINEZ S.S. O NIM Azadirachta indica: natureza, usos múltiplos, produção. Londrina, IAPAR- Instituto Agronômico do Paraná, 2002. 142p.

MORAES, G.J.; FLECHTMANN, C.H.W. Manual de acarologia. Acarologia básica e ácaros de plantas cultivadas no Brasil. Ribeirão Preto-SP: Holos, 2008. 308p.

MORDUE (LUNTZ), J.A.; ALASDAIR J. NISBET. Azadirachtin from the neem tree Azadirachta indica: its action against insects. Anais da Sociedade Entomológica do Brasil, v.29 n.4, p.615632, 2000. Available from: <http://dx.doi.org/10.1590/S030180592000000400001>. Accessed: Aug. 19, 2015.

OLIVEIRA, R.C. et al. Entomopathogenic fungi selection to control Oligonychus yothersi (McGregor) (Acari: Tetranychidae) in Paraguay tea crops (Ilex paraguariensis St. Hill.). Neotropical Entomology, v.33, n.3. p.347-351, 2004. Available from: <http://dx.doi.org/10.1590/ S1519-566X2004000300012>. Accessed: Aug. 10, 2014

PASINI. A. et al. Preliminary assays for efficiency evaluation of neem oil for control of Oligonychus yothersi (Acari: Tetranychidae). Semina: Ciências Agrárias, v.24, n.2, p.315-316, 2003.

PEDRO NETO, $M$. et al. Influence of rainfall on mite distribution in organic and conventional coffee systems. Coffee Science, v.5, n.1, p.6774, 2010. Available from: <http://www.alice.cnptia.embrapa.br/bitstream/ doc/880483/1/Influenceofrainfall.pdf > . Accessed: May 15, 2015.

SCHLESENER, D.C.H. et al. Effects of neem on Tetranychus urticae Koch (Acari: Tetranychidae) and the predators Phytoseiulus macropilis (Banks) e Neoseiulus californicus (McGregor) (Acari: Phitoseiidae). Revista Brasileira de Fruticultura, v.35, n.1, p.59-66, 2013. Available from: <http://dx.doi.org/10.1590/S010029452013000100008>. Accessed: July 10, 2015.

SCHMUTTERER, H.. Properties and potential of natural pesticides from the neem tree, Azadirachta indica. Annual Review of Entomology, v.35, p.271-297, 1990. Available from: $<$ http://arjournals.annualreviews.org/doi/abs/10.1146/annurev. en.35.010190.001415>. Accessed: Jul, 2015.

SILVA, E.R.L. et al. Study of red mite Oligonychus yothersi (Acari: Tetranychidae) behavior on Paraguay tea leaves. Scientia Agraria Paranaensis, v.1, n.2, p.11-20, 2001.

SOUZA, A.P. de; VENDRAMIM, J.D. Translaminar, sistemic and topical effect of aqueous extract of neem seed on Bemisia tabaci (Genn.) biotype B on tomato plants. Neotropical Entomology, v.34, n.1, p.83-87, 2005. Available from: <http://dx.doi.org/10.1590/ S1519-566X2005000100012>. Accessed: Feb. 10, 2014 